\title{
Systemic disease in turbot Scophthalmus maximus caused by a previously unrecognised Cytophaga- like bacterium
}

\author{
M. Mudarris*, B. Austin** \\ Department of Brewing and Biological Sciences, Heriot-Watt University, Edinburgh EH1 1HX, Scotland
}

\begin{abstract}
A new group of Cytophaga-like bacteria has been recovered from healthy and diseased turbot in Scotland. Cultures produced orange colonies and contained short rods with distinctively thick cell walls. Gliding movement was observed and the guanine plus cytosine ratio of the DNA was 31.7 to $32.1 \mathrm{mols} \%$. The organism caused gill hyperplasia and systemic haemorrhagic septicaemia in both naturally diseased and experimentally infected tubot. Control of the disease was possible by administering an injection or bath of furazolidone.
\end{abstract}

\section{INTRODUCTION}

In a previous study, suitable methods were developed for the recovery of bacteria from the gills of turbot Scophthalmus maximus L. (Mudarris \& Austin 1988). A nutrient limited medium was formulated, designated as medium $K$, which was especially suitable for the isolation and maintenance of aerobic heterotrophic bacteria occurring on gill tissue. Using this medium, gill bacteria from turbot were enumerated and then identified using conventional diagnostic schemes (e.g. Starr et al. 1981). The bacterial cultures were also examined for possible deleterious effects on fish. During this investigation, cultures forming a single group of orange-pigmented Gram-negative rods with low DNA guanine plus cytosine ratios and gliding motility, i.e. Cytophaga, caused gill hyperplasia and a generalised haemorrhagic septicaemia in juvenile turbot. The significance of these findings was reinforced by the outbreak of a disease in farmed turbot in Scotland during 1987 caused by a similar bacterium. The results of bacteriological examinations of the disease are reported here. Details of the histopathology of the disease will be presented separately (Mudarris \& Austin unpubl).

- On sabbatical leave from: Faculty of Marine Science, King Abdulaziz University, PO Box 1450 Jeddah, Saudi Arabia - Addressee for reprint requests

\section{MATERIALS AND METHODS}

Fish. Juvenile turbot (average weight $=100 \mathrm{~g}$ ) were obtained from a commercial fish farm in Scotland. These were maintained within the laboratory in glass aquaria containing aerated re-circulating seawater at ca $18^{\circ} \mathrm{C}$. Adult turbot (average weight $=2.5 \mathrm{~kg}$ ) displaying clinical signs of disease (i.e. lethargy, haemorrhaging in the gills, distended abdomens, and an assortment of surface lesions) were obtained directly from a fish farm and from holding facilities within Heriot-Watt University. In addition, wild fish (and water samples) were obtained from the mouth of the River Forth (Firth of Forth) near Edinburgh, Scotland.

Isolation of bacteria from turbot. From healthy fish, gill tissue $(1.0 \mathrm{~g})$ was homogenised, and dilutions to $10^{-4}$ were prepared in $10 \mathrm{ml}$ aliquots of sterile $\left(121^{\circ} \mathrm{C} /\right.$ $15 \mathrm{~min}$ ) seawater. Approximately $10 \mathrm{~cm}^{2}$ areas of skin from the middle of the dorsal surface were swabbed (Exogen, cotton-tipped swabs) vigorously for ca $15 \mathrm{sec}$. With diseased turbot, samples of gill, skin, kidney, ascitic fluid, and intestinal contents were homogenised or swabbed, as appropriate. Diluted samples $(0.1 \mathrm{ml})$ and swabbed material were inoculated onto triplicate plates of brain heart infusion agar (BHIA; Oxoid), glucose yeast extract agar (GYEA; Oxoid), marine 2216E agar (Difco), and medium K. Incubation was at $25^{\circ} \mathrm{C}$ for up to $14 \mathrm{~d}$. Thereafter, colony counts were made, and pure cultures were prepared by streaking and restreaking on fresh media. Purity was confirmed by the 
examination of Gram-stained smears (Hucker \& Conn 1923). The pure cultures were maintained on slopes of medium $\mathrm{K}$ at $4^{\circ} \mathrm{C}$, with transfer every 6 to $8 \mathrm{wk}$. Stock cultures were also freeze-dried.

Examination of bacterial isolates. Cultures were examined for a wide range of phenotypic and genotypic characteristics. The phenotypic traits included all tests considered to have diagnostic and differential value for Gram-negative pigmented gliding bacteria (Starr et al. 1981). Methods were adapted from Cowan (1974), van der Meulen et al. (1974), and Gerhardt et al. (1981). The features examined included colonial (notably the presence of flexirubin pigments as determined by the production of a purple colour by colonies after the addition of $20 \%$ [w/v] potassium hydroxide) and cell-morphology; the presence of gliding on medium $\mathrm{K}$; the oxidative or fermentative metabolism of glucose; the production of ammonia (from arginine), arginine dihydrolase, catalase, $\mathrm{H}_{2} \mathrm{~S}$, indole, lysine and ornithine decarboxylases, methyl red reaction, nitrate reduction, oxidase, phenylalanine deaminase, phosphatase and the Voges-Proskauer reaction; the production of acid from arabinose, cellobiose, glucose, lactose, mannitol, raffinose, salicin, sucrose, and xylose; the degradation of aesculin, agar, blood $(\beta$ haemolysis), casein, cellulose, chitin, DNA, gelatin, starch, tríbutyrin, Tween 20,40, 60, 80 and 85, tyrosine, and urea; the utilization of alginate, Larabinose, L-arabitol, carboxymethyl cellulose, cellobiose, erythritol, ethanol, D-fructose, D-glucose, glycerol, heparin, inositol, inulin, L-leucine, lysine, maltose, mannitol, methanol, L-methionine, pectin, L. phenylalanine, polypectate, raffinose, D-ribose, sodium benzoate, sodium citrate, sodium succinate, sorbitol, sucrose, D-xylitol, and D-xylose as the sole source of carbon for energy and growth; the utilization of sodium nitrate, vitamin - free casamino acids and yeast extract as the source of nitrogen; growth in 0 to

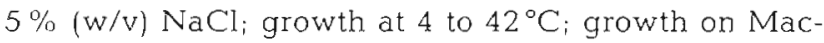
Conkey agar; and sensitivity to ampicillin $(10,25 \mu \mathrm{g})$, carbenicillin $(100 \mu \mathrm{g})$, chloramphenicol $(10,50 \mu \mathrm{g})$, chlortetracycline $(10 \mu \mathrm{g})$, cephaloridine $(25 \mu \mathrm{g})$, cloxacillin $(5 \mu \mathrm{g})$, colistin sulphate $(10 \mu \mathrm{g})$, co-trimoxazole (25 $\mathrm{ug})$, erythromycin (10 $\mathrm{ug})$, furazolidone $(50 \mu \mathrm{g})$, fusidic acid $(10 \mu \mathrm{g})$, gentamicin $(10 \mu \mathrm{g})$, kanamycin $(30$ $\mu \mathrm{g})$, lincomycin $(2 \mu \mathrm{g})$, methicillin $(10 \mu \mathrm{g})$, nalidixic acid $(5,30 \mu \mathrm{g})$, neomycin $(10 \mu \mathrm{g})$, nitrofurantoin $(200$ $\mu \mathrm{g})$, novobiocin $(5 \mu \mathrm{g})$, oleandomycin $(5 \mu \mathrm{g})$, oxytetracycline $(10 \mu \mathrm{g})$, penicillin G (1.5 IU), streptomycin (10, $25 \mu \mathrm{g})$, sulphadiazine $(50 \mu \mathrm{g})$, sulphafurazole $(100,500$ $\mu \mathrm{g})$, and tetracycline $(10,50 \mu \mathrm{g})$.

DNA base composition. DNA was extracted and purified by the method of Mandel et al. (1971). The base composition was determined from $T_{m}$ values (Marmur \& Doty 1962).
Fish experiments. Groups containing 6 juvenile turbot (average weight $=100 \mathrm{~g}$ ) were maintained in aerated re-circulating seawater at $18^{\circ} \mathrm{C}$. In addition, rainbow trout Salmo gairdneri (average weight $=19 \mathrm{~g}$ ) were kept in aerated fresh water, also at $18^{\circ} \mathrm{C}$. The fish were infected, via intraperitoneal injection with either $10^{7}, 10^{5}$, or $10^{2}$ cells of a representative strain, i.e. strain $M M_{1}$, suspended in either $0.5 \mathrm{ml}$ volumes of $0.9 \%$ (w/ v) saline or in $0.2 \mathrm{ml}$ aliquots of distilled water for the turbot and rainbow trout, respectively. Negative and positive controls were also used and consisted of injections with saline and Vibrio anguillarum (NCMB 1873; National Collection of Marine Bacteria, Aberdeen, Scotland), respectively. Parallel experiments sought to examine the effect of immersion of groups of fish in suspensions containing $10^{7}$ bacterial cells $\mathrm{ml}^{-1}$ for 15 min. The fish were examined daily for up to $10 \mathrm{~d}$. Following challenge, bacteriological (as described above) and histological examinations were carried out on all dead and moribund fish. The effect of intraperitoneal injections with $0.5 \mathrm{mI}$ volumes of $0.9 \%$ $(\mathrm{w} / \mathrm{v})$ saline containing culture supernatants (1 g dry $w t)$, cell homogenates (5 $\mathrm{mg}$ dry wt), or lipopolysaccharide (LPS) (0.2 $\mathrm{mg}$ dry wt) preparations was also examined. Here, the relevant methods followed those of Schnaitman (1970), Saeed \& Plumb (1986) and Neidhardt (1987). The findings of the histological examination will be reported separately (Mudarris \& Austin unpubl.). Potential control of the disease was examined by administering furazolidone or sulphafurazole to infected turbot, either by single intraperitoneal injection $(50,100 \mathrm{mg} / \mathrm{kg}$ of body wt) or by bathing $\left(50,100 \mathrm{mg} \mathrm{l}^{-1}\right.$ for 30 min daily for $10 \mathrm{~d}$ ) when the initial signs of disease were observed.

Transmission electron microscopy. Dense suspensions in $0.85 \%(\mathrm{w} / \mathrm{v})$ saline were prepared from plate cultures. Suspensions were fixed overnight in $0.5 \%(\mathrm{v} /$ v) buffered ( $\mathrm{pH} 7.4$ ) glutaraldehyde. To determine cellmorphology, preparations were stained with $1 \%(\mathrm{v} / \mathrm{v})$ phosphotungstic acid. Thin sections were also prepared and stained according to Watson (1958), Millonig (1961), and Reynolds (1963). All prepared specimens were examined in an AEI EM6G transmission electron microscope (TEM).

\section{RESULTS}

\section{Recovery of orange pigmented gliding bacteria}

From the gills of healthy turbot a variety of orange pigmented Gram-negative bacteria, which demonstrated gliding movement, was recovered. These bacteria were consistently recovered in highest numbers on medium $\mathrm{K}$. On the basis of their phenotypic traits, these organisms were equated with Cytophaga and 
Flexibacter (Reichenbach \& Dworkin 1981). Based on the results of initial experiments, attention focused on an organism possessing the key traits of the genus Cytophaga; it was different from any of the currently recognised species of the genus included in the 'Approved lists of bacterial names' (Skerman et al. 1980 ) or their supplements. Low numbers, i.e. ca 0.1 to $1.0 \%$ of the total number of colonies on medium $\mathrm{K}$, of this organism were consistently recovered from the gills of all healthy juvenile and adult turbot. Moreover, an identical organism was recovered as dense pure culture growth from the gills and internal organs of clinically diseased turbot obtained from an external site, and from the wild. These fish displayed gill disease and a systemic haemorrhagic septicaemia. It should be emphasised, that as a result or routine histopathological and microbiological examinations, there was no evidence of infection by viruses, parasites or other bacteria in these fish. Additional cultures of the Cytophaga-like bacterium were obtained from the water of the Firth of Forth. Here, cultures accounted for ca $0.1 \%$ of the total number of colonies recovered on medium K. In total, 50 cultures, considered to represent a single taxonomic group of the genus Cytophaga, were examined in detail.

\section{Characteristics of the Cytophaga-like bacteria}

All isolates produced round, raised, shiny orange pigmented (flexirubin pigment) colonies of 2 to $3 \mathrm{~mm}$ diam. in $48 \mathrm{~h}$ of incubation at $25^{\circ} \mathrm{C}$ on medium $\mathrm{K}$. Cultures contained uniformly shaped short fermentative Gram-negative rods of ca $2.0 \times 0.8 \mu \mathrm{m}$ in size, which showed gliding movement. Neither flagella nor resting stages were observed. Examination of thin sections by TEM revealed the presence of a thick (43.5 nm) cell envelope (Fig. 1) which was initially mistaken for an extracellular layer. In fact, the thickness was double (i.e. $\sim 20 \mathrm{~nm}$ ) that of bona fide Cytophaga, such as $C$. aquatilis (Strohl \& Tait 1978), and other Gram-negative bacteria (Costerton et al. 1974). Additional characteristics of the bacterium are listed in Table 1. The guanine plus cytosine ratio of the DNA from a representative strain $\left(\mathrm{MM}_{1}\right)$ was 31.7 to $32.1 \mathrm{mols} \%$.

\section{Pathogenicity}

Naturally diseased turbot, from which the Cytophaga-like bacterium was recovered, displayed swollen gill lamellae (hyperplasia) and haemorrhagic septicaemia. Externally, haemorrhaging was evident in the eyes, skin, and jaw. Internally, there was necrosis/ haemorrhaging in the brain, stomach, intestinal tract,

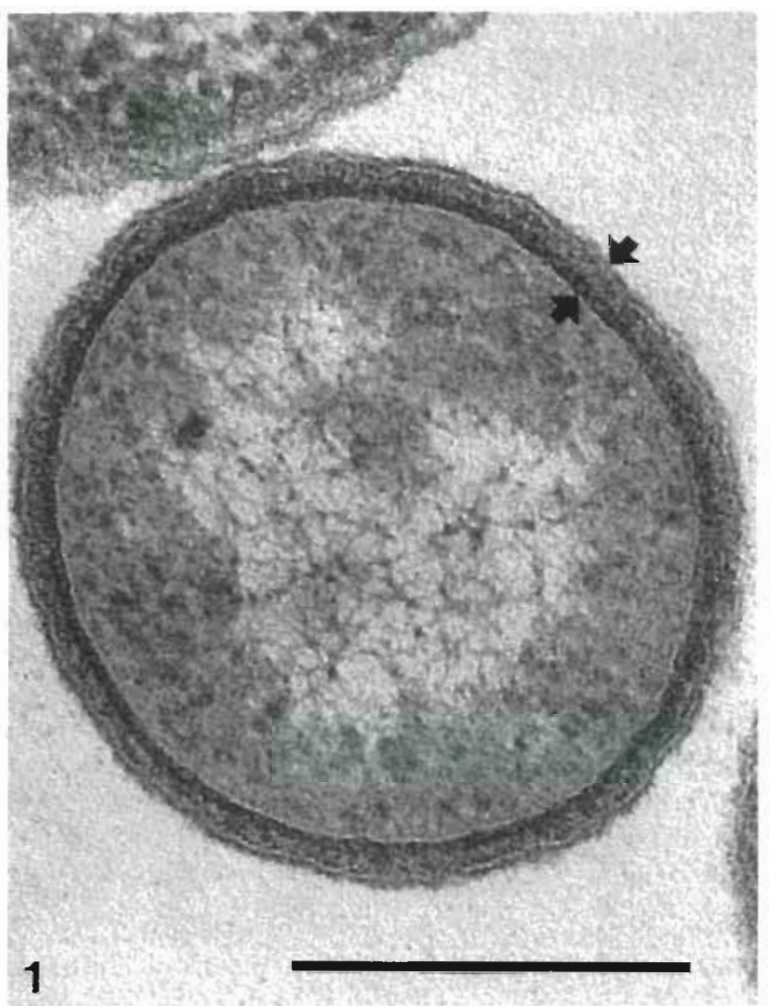

Fig. 1. Cytophaga-like bacterium. Transmission electron micrograph of thin section. Note presence of thick cell envelope (arrow). It should be emphasised that most preparations contained obviously rod-shaped rather than coccoid cells. This photograph probably represents a transverse section of a cell, and has been included because of the clear demonstration of the thick cell envelope. Bar $=2.25 \mu \mathrm{m}$

liver, and kidney. Ascitic fluid was present in the peritoneal cavity. The intestine was swollen and contained a yellowish fluid.

With juvenile turbot, there was $100 \%$ mortality within $2 \mathrm{~d}$ following infection with $10^{7}$ cells. With challenges of $10^{5}$ and $10^{2}$ cells, mortalities were lower: $80 \%$ and $30 \%$, respectively. By immersion, the disease signs developed after $5 \mathrm{~d}$, with mortalities occurring $2 \mathrm{~d}$ later. Interestingly with trout, injection of $10^{7}$ cells resulted in $70 \%$ mortalities within $5 \mathrm{~d}$. All dead fish displayed the same signs described above except that in trout there was no evidence of gill damage. Pure culture growth of the challenge organism was recovered from the internal organs. Interestingly, use of Vibrio anguillarum for control purposes produced $100 \%$ mortality among infected fish with haemorrhagic septicaemia but no involvement with the gills. Injection of fish with cell supernatant and LPS did not result in any disease signs. However, injection of cell homogenates produced clinical disease, notably the presence of swollen oedematous gill lamellae, and haemorrhaging in the stomach, intestinal tract, kidney, and liver 
Table 1. Characteristics (percentage positive response of 50 tested isolates) of the fish-pathogenic Cytophaga-like bacteria isolated from turbot Scophthalmus maximus

\begin{tabular}{|c|c|c|c|}
\hline Character & $\begin{array}{l}\% \text { positive } \\
\text { response }\end{array}$ & Character & $\begin{array}{l}\% \text { positive } \\
\text { response }\end{array}$ \\
\hline \multicolumn{4}{|l|}{ Biochemical tests: } \\
\hline Acid production from sugars (listed in text) & 0 & Inositol & 0 \\
\hline Ammonia from arginine & 100 & Inulin & 0 \\
\hline Arginine dihydrolase & 0 & L-leucine & 0 \\
\hline Catalase production & 100 & Lysine & 0 \\
\hline $\mathrm{H}_{2} \mathrm{~S}$ production & 0 & Maltose & 100 \\
\hline Indole & 0 & Mannitol & 0 \\
\hline Lysine decarboxylase & 0 & Methanol & 0 \\
\hline Methyl red test & 0 & L-methionine & 0 \\
\hline Nitrate reduction & 0 & Pectin & 100 \\
\hline Ornithine decarboxylase & 0 & L-phenylalanine & 0 \\
\hline Oxidase production & 100 & polypectate & 82 \\
\hline Phenylalanine deaminase & 82 & Raffinose & 0 \\
\hline Phosphatase & 86 & D-ribose & 0 \\
\hline \multirow[t]{2}{*}{ Voges-Proskauer reaction } & 0 & Sodium benzoate & 0 \\
\hline & & Sodium citrate & 16 \\
\hline Growth at/on: & & Sodium succinate & 0 \\
\hline $15-25^{\circ} \mathrm{C}$ & 100 & Sorbitol & 0 \\
\hline $4^{\circ} \mathrm{C}$ & 80 (weak) & Sucrose & 0 \\
\hline $35^{\circ} \mathrm{C}$ & 0 & D-xylitol & 100 \\
\hline $0-4 \%(\mathrm{w} / \mathrm{v}) \mathrm{NaCl}$ & 100 & D-xylose & 0 \\
\hline $5 \%(\mathrm{w} / \mathrm{v}) \mathrm{NaCl}$ & 0 & & \\
\hline MacConkey agar & 0 & Utilization, as sole nitrogen source: & \\
\hline \multicolumn{2}{|l|}{ Degradation of: } & Casamino acids, vitamin-free & 100 \\
\hline Aesculin & 88 & Sodium nitrate & 100 \\
\hline Agar & 0 & Yeast extract & 100 \\
\hline Blood ( $\beta$-haemolysis) & 84 & & \\
\hline Casein & 84 & Susceptibility to: & \\
\hline Cellulose & 0 & Ampicillin $(25 \mu \mathrm{g})$ & 80 \\
\hline Chitin & 0 & Carbenicillin $(100 \mu \mathrm{g})$ & 78 \\
\hline DNA & 100 & Chloramphenicol $(50 \mu \mathrm{g})$ & 100 \\
\hline Gelatin & 96 & Chlortetracyline $(10 \mu \mathrm{g})$ & 0 \\
\hline Starch & 0 & Cephaloridine $(25 \mu \mathrm{g})$ & 16 \\
\hline Tributyrin & 80 & Cloxacillin $(5 \mu \mathrm{g})$ & 0 \\
\hline Tween 20 & 82 & Colistin sulphate $(10 \mu \mathrm{g})$ & 2 \\
\hline Tween 40 & 88 & Co-trimoxazole $(25 \mu \mathrm{g})$ & 100 \\
\hline Tween 60 & 82 & Erythromycin $(10 \mu \mathrm{g})$ & 90 \\
\hline Tween 80 & 92 & Furazolidone $(50 \mathrm{~kg})$ & 100 \\
\hline Tween 85 & 86 & Fusidic acid $(10 \mu \mathrm{g})$ & 100 \\
\hline Tyrosine & 96 & Gentamicin $(10 \mu \mathrm{g})$ & 0 \\
\hline \multirow{2}{*}{ Urea } & 86 & Kanamycin $(30 \mu \mathrm{g})$ & 0 \\
\hline & & Lincomycin $(2 \mu \mathrm{g})$ & 0 \\
\hline Utilization, as sole carbon source: & & Methicillin $(10 \mu \mathrm{g})$ & 0 \\
\hline Alginate & 0 & Nalidixic aid $(30 \mu \mathrm{g})$ & 18 \\
\hline L-arabinose & 0 & Neomycin $(10 \mu \mathrm{g})$ & 2 \\
\hline L-arabitol & 0 & Nitrofurantoin $(200 \mu \mathrm{g})$ & 96 \\
\hline Carboxymethylcellulose & 0 & Novobiocin $(5 \mu \mathrm{g})$ & 100 \\
\hline Cellobiose & 88 & Oleandomycin $(5 \mu \mathrm{g})$ & 0 \\
\hline Erythritol & 0 & Oxytetracycline $(10 \mu \mathrm{g})$ & 0 \\
\hline Ethanol & 100 & Penicillin G (1.5 IU) & 0 \\
\hline D-fructose & 100 & Streptomycin $(25 \mu \mathrm{g})$ & 0 \\
\hline D-glucose & 100 & Sulphadiazine $(50 \mu \mathrm{g})$ & 0 \\
\hline Glycerol & 0 & Sulphafurazole $(100 \mu \mathrm{g})$ & 82 \\
\hline Heparin & 0 & Tetracycline $(50 \mu \mathrm{g})$ & 0 \\
\hline
\end{tabular}


Control of the disease was possible by injection ( $83 \%$ survival) and bathing (50\% survival) with furazolidone at $50 \mathrm{mg}$ per $\mathrm{kg}$ body wt of fish and $50 \mathrm{mg} \mathrm{l}^{-1}$, respectively. In contrast, with sulphafurazole, only 33 and $17 \%$ of the population survived injection and bathing, respectively. All of the untreated fish in the control group died in $4 \mathrm{~d}$.

\section{DISCUSSION}

An organism causing a gill and systemic disease has been recovered from turbot in the South of Scotland. In laboratory challenges the organism produced a disease which clearly resembled the natural infection. The organism may not be obligately marine because growth was recorded in $0 \%(\mathrm{w} / \mathrm{v}) \mathrm{NaCl}$. The organism was equated with the genus Cytophaga because of its cell and colonial morphology, its gliding motility, and the guanine plus cytosine ratio of its DNA (Reichenbach \& Dworkin 1981). It differed from any of the taxa of fish pathogens included in Austin \& Austin (1987) and from any of the validly recognised species of Cytophaga. Although it appears likely that the organism represents a new species of Cytophaga, it should be emphasised that the genus is heterogeneous and may warrant sub-division into two or more genera (Reichenbach \& Dworkin 1981). For this reason, the organism should be regarded as a Cytophaga-like bacterium until future improvements in the taxonomy of the genus Cytophaga permit a more definitive identification. It is noteworthy that the bacterium caused a haemorrhagic condition in fish, especially as haemorphagic lesions are not usually associated with gliding bacteria (Austin \& Austin 1987). There can be little doubt, however, that it was the responsible agent because other systemic microorganisms were not recovered from the experimentally or naturally infected fish.

From the results of this study, it is considered that the Cytophaga-like bacterium may well form part of the normal gill microflora of healthy turbot. This possibility agrees with the scenario for Cytophaga pathogens of penaeids, proposed by Lightner (1985). The change in status from harmless saprophyte to pathogen may indicate the presence of as yet unknown factors that serve to weaken the host or to enhance bacterial aggressiveness. The overall importance of the organism to fish pathology remains to be properly elucidated. Nevertheless, the disease has been associated with both farmed and wild fish, albeit not in epizootic proportions. At present, it is considered that virulence factors may involve exotoxins, as illustrated by the proteolytic activity. Certainly, further work should be directed at the unusually thick cell envelope, which may be involved with the pathogenic mechanism.
A culture of the Cytophaga-like bacterium, strain $\mathrm{MM}_{1}$, has been deposited in the Czechoslovak Collection of Microorganisms, J.E. Purkyňe University, 66243 Brno, Czechoslovakia, as CCM 1409.

Acknowledgements. Mr J. Buchanan is acknowledged for excellent assistance with the TEM and photography. One of us, M. M. was in receipt of a scholarship from the Saudi Arabian Government.

\section{LITERATURE CITED}

Austin, B., Austin, D. A. (1987). Bacterial fish pathogens, disease of farmed and wild fish. Ellis Horwood, Chichester

Costerton, J. W., Ingram, J. M., Cheng, K.-J. (1974). Structure and function of the cell envelope of Gram-negative bacteria. Bact. Rev. 38: 87-110

Cowan, S. T (1974). Cowan \& Steel's manual for the identification of medical bacteria, 2nd edn. Cambridge University Press, Cambridge

Gerhardt, P., Murray, R. G. E., Costilow, R. N., Nester, E. W. Wood, W. A., Krieg, N. R., Phillips, G. B. (1981). Manual of methods for general bacteriology. American Society of Microbiology, Washington (D.C.)

Hucker, G. J., Conn, H. J. (1923). Methods of gram staining. Tech. Bull. N.Y St. Agric. Exp. Stn 23

Lightner, D. V (1985). A review of the diseases of cultured penaeid shrimp and prawns with emphasis on recent discoveries and developments. In: Taki, Y., Primavera, J. H., Llobrera, J. A. (eds.) Proc. 1st Int. Conf. Cult. Penaeid Prawns/Shrimps, Iloilo City, Philippines, p. 79-103

Mandel, M., Leadbetter, E. R., Pfennig, N., Trüper, H. G. (1971). Deoxyribonucleic acid base composition of phototrophic bacteria. Int. J. System. Bact. 21: 222-230

Marmur, J., Doty, P. (1962). Determination of the base composition of deoxyribonucleic acid from its thermal denaturation temperature. J. molec. Biol. 5: 109-118

Millonig, G. (1961). A modified procedure for lead staining of thin sections. J. biophys, biochem. Cytol. 11: 736

Mudarris, M., Austin, B. (1988). Quantitative and qualitative studies of the bacterial microflora of turbot, Scophthalmus maximus L., gills. J. Fish Biol. 32: 223-229

Neidhardt, F. C. (1987). Escherichia coli and Salmonella typhimurium, cellular and molecular biology. American Society of Microbiology, Washington (D.C.)

Reichenbach, H., Dworkin, M. (1981). The order Cytophagales (with addenda on the genera Herpetosiphon, Saprospira and Flexithrix). In: Starr, M. P., Stolp, H., Trüper, H. G., Balows, A., Schlegel, H. G. (eds.) The prokaryotes, a handbook on habitats, isolation and identification of bacteria, Vol. 1, Chap. 21. Springer-Verlag, Berlin, p. 356-379

Reynolds, E. S. (1963). The use of lead citrate at high $\mathrm{pH}$ as an electron-opaque stain in electron microscopy. J. Cell Biol. 17: 208-212

Saeed, M. O., Plumb, J. A. (1986). Immune response of channel catfish to lipopolysaccharide and whole cell Edwardsiella ictaluri vaccines. Dis. aquat. Org. 2: 21-25

Schnaitman, C. A. (1970). Protein composition of the cell wall and cytoplasmic membrane of Escherichia coli. J. Bact 104: 890-901

Skerman, V B. D., McGowan, V., Sneath, P. H. A. (1980) Approved lists of bacterial names. Int. J. System. Bact. 30 $225-420$ 
Starr, M. P., Stolp, H., Trüper, H. G., Balows, A., Schlegel, H. G. (eds.) (1981). The prokaryotes, a handbook on habitats, isolation and identification of bacteria. Springer-Verlag, Berlin

Strohl, W. R., Tait, L. R. (1978). Cytophaga aquatilis sp. nov, a facultative anaerobe isolated from the gills of freshwater fish. Int. J. System. Bact. 28: 293-303 van der Meulen, H. J., Harder, W., Veldkamp, H. (1974) Isolation and characterization of Cytophaga flevensis sp. nov., a new agarolytic flexibacterium. Antonie van Leeuwenhoek 40: 329-346

Watson, M. L. (1958). Staining of tissue sections for electron microscopy with heavy metals. J. biophys. biochem. Cytol. 4: 475

Responsible Subject Editor: Dr T Evelyn; accepted for printing on March 31, 1989 